\title{
Morte saturnal e tanatografia em François Rabelais
}

\author{
Tanatography and Saturnalia Death in François Rabelais
}

Augusto Rodrigues da SILVA JUNIOR*

Universidade de Brasília (UnB)

\begin{abstract}
RESUMO: O objetivo deste artigo é analisar os livros Gargântua e Pantagruel, de François Rabelais, em perspectiva tanatográfica. Isto significa dizer que mapeamos as ocorrências da morte saturnal no romance francês e suas estilizações literárias. Comparando o livro (os cinco volumes) com algumas obras da tradição e situando-o no campo da cultura fúnebre pretendemos discutir a catábase: a forma escolhida por Rabelais para integrar uma longa tradição de defuntos personagens que falam e/ou que voltam para contar.
\end{abstract}

PALAVRAS-CHAVE: Morte saturnal. Tanatografia. Rabelais. Bakhtin.

RESUMÉ: La proposition du cet essaiest d'examiner les livres Gargântua et Pantagruel (François Rabelais) en perspective thanatographique. Ce la signifie que nous vont réfléchir sur de la mort saturnale dans le roman français et ses stylisations littéraires. En comparant le livre (les cinq volumes) avec quelques œuvres dela tradition et dans le domaine de la culture funéraire notre intention est de discupter la catabase: cette forme choisie par Rabelais pour intégrer une longue histoire de personnages morts qui parlent, ou qui renvoyés à raconter par les vivants.

MOTS-CLÉ: Mort saturnale. Thanatographie. Rabelais. Bakhtin.

\section{Introdução}

Em uma longa tradição de uma escrita da morte na literatura, François Rabelais também escreveu o seu diálogo dos mortos. Os seus volumes de Gargântua e Pantagruel, consolidam sua concepção de morte alegre e a ida de um personagem ao inferno saturnal, que volta para contar, por meio da ressurreição, o colocam nesta longa prática tanatográfica ${ }^{1}$.

Algumas sátiras de Luciano (Séc. II) já presentificavam o advento do cristianismo e riam das conversões miraculosas de romanos frente a um, aparentemente, frágil teocentrismo. Com o advento desta religião, o finamento se transforma e a representação se contamina com o sério (religioso) e com o riso (popular, religioso e pagão). Na Europa, as manifestações medievais das Líber vitae, Soties religiosas, ArsMoriendi, dramas epifrásicos e mistérios prevaleceram próximos à Igreja e aos cemitérios, ou então, afastados e condenados pela censura católica. Na literatura, os dramas e a poesia dos infernos (SOUSA, 2013, p. 29) de modo geral, na condição autoral específica, apresentam algumas importantes manifestações da tanatografia: O Canto XI da Odisseia (de Homero), As rãs (de Aristófanes), A Sátira Menipeia (Luciano), A Divina Comédia (Dante), Peças

\footnotetext{
* Doutor em Literatura Compara pela Universidade Federal Fluminense. Prof. Adjunto II de Literatura Brasileira do Departamento de Teoria Literária e Literaturas da Universidade de Brasília (TEL/UnB). Brasília-DF. Email: augustorodriguesdr@gmail.com

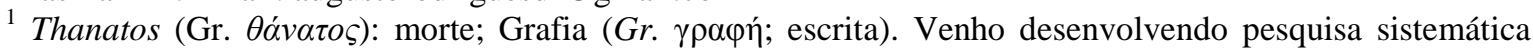
desde 1998 sobre uma escrita da morte na literatura a partir do defunto autor Brás Cubas.
} 
medievais, tais como os Autos da Barca do Inferno, da Barca do purgatório e da Barca da Glória (de Gil Vicente).

Para Santo Agostinho (2008) [Séc. V] os vivos e os mortos deveriam permanecer distantes. Com isto, ele aponta para uma limitação material e de culto aos antepassados. Os viventes deveriam dirigir-se a Deus para salvarem-se e salvarem os seus. Em seus escritos, ele acredita na revelação pelo sonho e não pela presença mundana do fantasma. Sua teoria das visões (corporais, espirituais e intelectuais) predomina até mais ou menos o século XII e mantém implícita a compreensão do purgatório para o período medieval.

A obra de Rabelais, voltada para festejar a vida, elaborada por um autor cristão de formação franciscana, também celebra um cristianismo corporificado. As mortes, quando em grande número, retratam o grande corpo da multidão formado pela humanidade e são ligadas pela história e por Deus. O elemento popular, as lutas do homem medieval, o ápice de sua expressão cultural, são retratados de forma realista. No caso das guerras, ocorrem as paródias do épico e do cavaleiresco que enumeram grandes conjuntos de pessoas cujo trespasse se dá em grandes batalhas, doenças e pragas dizimadoras. Mas as perdas, embora lamentadas, equacionam o caminho em direção ao sagrado paradisíaco e à continuidade no corpo contínuo da humanidade.

O Paraíso, especificamente, nunca é descrito em Gargântua e Pantagruel, mas uma paródia da descida ao Hades proporciona uma visão do inferno saturnal rabelaisiano. Nosso artigo reside na análise desta catábase paradigmática para a história da literatura.

A ressurreição e a alegria predominam diante das agruras e carestia medieval. Isso não exclui o decesso: nas grandes batalhas, um número imenso de corpos; na morte da mãe de Pantagruel, que falece no seu nascimento, ocorre simbolicamente a fecundação e a renovação carnavalesca; falecimentos de figuras da Antiguidade, para elogiá-las ou destroná-las, também são frequentes; e descrições de trespasses épicos reelaboram os modos de morrer no Século XVI.

No Livro II ("anos de formação" de Gargântua) vemos as transformações do ideário medieval e a paródia rabelaisiana que conjuga a Ilíada, o Canto XI da Odisséia, a ressurreição de Cristo coletada dos Evangelhos e recontada pela Idade Média, os espaços luciânicos e dantescos, bem como a perspectiva saturnal que promove inversões cômicas e paródicas.

Para o cristianismo medieval morrer era estar em um lugar de espera (requies) entre o desprendimento físico e o fim dos tempos (refrigerium). O julgamento, muito forte nos textos de Dante e de Gil Vicente, passou por diversas transformações ao longo dos séculos. Acompanhando as mudanças em todas as áreas do conhecimento, a Igreja, governou com mão de ferro em alguns momentos. Em outros, contornava imprevistos e ressignificava suas imagens de acordo com as necessidades - suas e dos fiéis. Captando e inferindo novas formas de condenar e manter as pessoas atadas pelo medo do fim, ou pela alegria do culto, o catolicismo utilizou-se dessa imagem como base de seus preceitos.

Os documentos dessa época são variados: os necrológios, os anais fúnebres, Libri Memoriales e manuais litúrgicos professam a presença do macabro no imaginário medieval. Dada a precariedade das condições de higiene e saúde, guerras constantes, as ações da Inquisição, o homem convivia materialmente com a perda iminente do outro e de si mesmo. A memória sepulcral que demarcava a duração de determinado grupo no tempo e a auto-confirmação da sua origem, trajetória e reconhecimento, foi importantíssima para o surgimento e propagação de vários gêneros biográficos: cartas, atas de concílios, registros de banquetes fúnebres (velórios). Os exemplos desta prática enformam o realismo rabelaisiano, bem como os gêneros apontados aparecem estilizados em suas obras. 


\title{
2 Breve história literária da morte
}

Erich Auerbach (2001), no capítulo "O mundo na boca de Pantagruel", indica que os gêneros Eclesiásticos e, principalmente, a liberdade na composição de sermões anteciparam a mistura de gêneros romanceada por Rabelais:

\begin{abstract}
Esta espécie de mistura de estilos não foi inventada por Rabelais; contudo ele pôs a serviço do seu temperamento e dos seus fins, mas a sua origem, paradoxalmente, está nos sermões de fins da Idade Média, nos quais a tradição cristã da mistura de estilos tinha se exacerbado até o extremo: estes sermões são, simultaneamente, populares, na mais crua das acepções, criaturalmente realistas, sábios e edificantes no sentido bíblico-figural-interpretativo (AUERBACH, 2001, p. 236-237).
\end{abstract}

Esta mistura de estilos e a compreensão realista da aproximação entre os gêneros incidem no conceito bakhtiniano de catolicismo carnavalizado - também, de origem franciscana (BAKHTIN, 2002a, p. 50). A única diferença é que o crítico russo faz uma leitura ambivalente que extrapola o figural, ao passo que Auerbach os limita à uma intensificação grotesca das proporções e dos elementos bíblico-interpretativos. Mas na perspectiva dialógica, nesta nossa crítica polifônica, "o mundo na boca e na garrafa" fornecem inúmeros campos estilísticos, cenários plurais e motivos tanatográficos. Se o Hadesluciânico já era um novo mundo, o que dizer do Inferno dantesco e do universo visitado por Alcofribas Nasier na boca de Pantagruel - outra viagem iluminada pela fantasia sério-cômica que permite elencar os mais diversos aspectos da realidade francesa do tempo do escritor e que reverbera nas releituras ao longo da história da recepção de Rabelais ${ }^{2}$. Elementos utópicos presentes na obra e na fantasia livre como marca profunda de seu romance e da cultura popular no contexto de François Rabelais.

Desde os tempos iniciais do cristianismo a Igreja ${ }^{3}$ utilizava representações de cunho didático para transmitir os ensinamentos. Os dramas litúrgicos utilizavam a música e a performance para alcançar um número maior de fiéis - visto que o latim muitas vezes não era compreendido, as festas religiosas tinham funções sociais e cada corporação possuía um ou mais Santos Padroeiros. Festas, peregrinações, longos dias de colheita e devoção entoavam os elementos de aproximação do grupo. As aglomerações permitiam a execução dos dramas e alegorias que deram origem aos Mistérios ou Milagres falados em vernáculo e representados por grupos itinerantes formados por leigos, artífices e comerciantes. $\mathrm{O}$ interesse dessas corporações nas apresentações e festividades era intenso porque elas atraíam muitas pessoas, impulsionavam o comércio e a formação de novas classes urbanas.

Mais especificamente, no campo da morte, há heranças dos banquetes fúnebres da Antiguidade, descritos por Tertuliano, comprovando que a noção da presença dos mortos entre os vivos foi profundamente assimilada pelo cristianismo primitivo: o ser ausente era invocado e convidado a um banquete eucarístico no sepultamento e/ou posteriormente. Nesse ritual o canto e a dança eram permitidos. A partir dos séculos IV-V foram proibidos e isso foi assimilado oficialmente nos rituais fúnebres eclesiásticos. Por outro lado,

\footnotetext{
${ }^{2}$ Para uma história da recepção rabelaisiana vide: William Shakespeare, de Victor Hugo - que compreende o fator positivo e autoconsciente da crítica de Rabelais no interior da própria Igreja e $O$ problema da incredulidade no século XVI, de Lucien Febvre que, apesar da importante contextualização do período não percebe que nas obras de Rabelais a incredulidade é discutida, mas nunca totalmente afirmada.

${ }^{3}$ Igreja, no imaginário medieval, designava o edifício e o espaço circundante. A paróquia congregava a nave, o sino e o cemitério.
} 
performances populares (Danças Macabras ${ }^{4}$ e teatralizações populares) mantiveram as características de rituais sepulcrais. Em forma de Mistérios e Moralidades, essa noção sobreviveria em diferentes modalidades dramáticas nas cerimônias do "Corpus Christi", Natal e Páscoa. As Soties (teatro e culto religioso moralista) foram cultivadas nas Igrejas em um ambiente dúplice de medo e devoção, carnaval e festa. Os intervalos das missas eram agraciados com pantomimas e breves textos que promoviam as missas em uma espécie de diálogo entre o sacerdote, o "coro" e as imagens. Os mistérios e peças cômicas (muitas vezes os gêneros se interpenetrando) eram carnavalizados com a introdução do riso, de diabruras, máscaras e músicas populares. Na celebração das Festas de Santo e do Corpo de Cristo era frequente a presença de preces jocosas, homilias paródicas, lendas sagradas burlescas, uma gama de pessoas dedicando-se às encenações. As próprias procissões medievais congregavam um caráter espetacularizado durante as obrigações e no entorno da Igreja (ARIÈS, 2003).

Contra as Carmina diabolica super mortuos, os cantos demoníacos (na vigília fúnebre), contra danças e pantomimas (saltationes), os jogos e brincadeiras (iocas) e as risadas altas (cachinni) a Igreja tomou medidas drásticas punindo aqueles que praticassem atos indevidos. O comer (manducare) e o beber (bibere) na presença do falecido passaram a ser considerados uma afronta, deturpando-se completamente a relação entre viventes e recordados e extirpando-se, em muitos casos, esses banquetes fúnebres. Somente na Alta Idade Média esta alegria mutilada será recuperada sob a pena católico-carnavalizadarenascentista de Rabelais. Todas estas proibições podem ser relacionadas aos personagens rabelaisianos: Ginasta com suas saltationes e jogos corporais; Panurge com brincadeiras e pantomimas; Frei Jean rindo alto enquanto come e bebe.

O lamento e o questionamento (juízo) sobre aquele que partiu impuseram o estranhamento clerical no lugar da familiaridade, eclipsando continuamente a interação (e diálogo) com os defuntos. Mas o discurso popular, a gargalhada sempre pronta ao enfrentamento na arena social, o jogo cômico, em todos os aspectos, permitiram um conjunto de paródias sagradas "[...] na unidade da cultura cômica popular da Idade Média" (BAKHTIN, 2002a, p. 72). Neste sentido, o riso medieval que vai habitar o contexto renascentista é universal e rivaliza com o sério. Abarca, também, a totalidade do mundo, a sociedade e concepções ideológicas - como o romance, enquanto gênero literário moderno, que se funda neste momento liminar da história.

Em Rabelais (nos Evangelhos) a morte não aparece em oposição à vida. O seu sistema de imagens grotescas entende o trespasse como uma entidade do todo. Bakhtin demonstra que ela é parte do processo de renovação permanente do grande corpo. A morte liga-se ao nascimento, o sepulcro vincula-se à terra que, por sua vez, oferece a existência:

\footnotetext{
No sistema de imagens grotescas, portanto, a morte e a renovação são inseparáveis do conjunto vital, e incapazes de infundir temor.

É preciso notar que no grotesco da Idade Média e do Renascimento há elementos cômicos mesmo na imagem da morte (até no campo pictórico, como por exemplo nas 'Danças Macabras' de Holbein e Dürer). [...] O tema da morte concebida como renovação, a superposição da morte e do nascimento e as imagens de mortos alegres têm um papel fundamental no sistema de imagens de Rabelais (BAKHTIN, 2002a, p. 44).
}

\footnotetext{
${ }^{4}$ Diz o camponês da dança macabra: "A morte é desejada frequentemente/ Mas de bom grado fujo dela:/ Gostaria mais, fizesse ele chuva ou vento/de ser vinha onde quer que fosse”; século XV (ARIÈS, 1977, p. 25).
} 
Este sistema, em cada volume, reconstrói-se. Na própria ideia de biografias de gigantes, o mundo já recebe um olhar diferente. As dimensões mudam e o grotesco é concebido como elemento de renovação. Os vivos alegres, na catábase rabelaisiana, enxergam o mundo dos mortos como um lugar carnavalizado, um espaço para o riso, para a inversão, o destronamento. Um bom exemplo desta morte que ri é a longa enumeração de falecimentos acidentais (exagerados) que o narrador traz no capítulo XVII do Livro IV "De como Pantagruel passou pelas ilhas de Tohu e Bohu; e da estranha morte de Briguenarilles, comedor de moinhos de vento". A primeira narrativa paródica descreve a estranha morte de Ésquilo, atingido por um casco de tartaruga lançado por uma águia. Ironia biográfica à parte, o narrador nos brinda com uma imensa galeria de fins biográficos estranhos e ambivalentes:

[...] o poeta Anacreonte, o qual morreu sufocado por uma pevide de uva. E Fábio pretor romano, o qual morreu sufocado por um pêlo de cabra, ingerido de um tigela de leite. E aquele envergonhado, que, por reter seu vento e receoso de peidar muito alto, morreu de repente na presença de Cláudio imperador romano. [...] Mais Zeuxis, o pintor, o qual morreu de repente à força de rir, olhando a cara de uma velha por ele apresentada em pintura. Mais mil outros que contam Plínio, ou Valério, Baptiste Fulgose, ou Bacabery o velho (RABELAIS, 1991, p. 90-91).

Diante deste necrológio paródico e histórico-biográfico infunde-se a imagem da morte alegre. Os trespasses descritos estão todos ligados aos orifícios. O corpo vivo ligado ao mundo pelos buracos. Não por acaso a enumeração acontece no capítulo de falecimento do comedor de moinhos. O moinho é a metáfora de um modo de ver e apreender o mundo: "[...] o princípio do redemoinho baralhador, que mistura as categorias do acontecer, da experiência, dos campos do saber, das proporções e dos estilos" (AUERBACH, 2001, p. 237). As guerras no livro de Rabelais são sempre contra personagens que encarnam o sério, o equilíbrio, a ordem, o acabamento.

Nos capítulos subsequentes, Pantagruel, Panurge e Frei Jean passam por uma tempestade e todos temem o pior, mas enfrentam o medo com palavrões e promessas (que nunca serão cumpridas!), desejos de se confessar e até mesmo se borrando - como o faz Panurge:

[...] Ai, ai, ai, disse Panúrgio, ai! Nu, bu, bu, bu, bu. Ah, ah! Será aqui que para perecer nos estava predestinado? Ah, boa gente, estou me afogando! Consummatum est. Estou frito. [...] Ai, ai, ai, arremedou Frei Jean. Como é feio esse chorão de merda. Grumete, ei, por todos os diabos, toma conta dele, Estás ferido? Virtude de deus, amarra esta trave. Assim, por parte do diabo, assim meu filho. - Ah! Frei Jean, disse Panúrgio, meu pai espiritual, meu amigo, não praguejemos. Pecais. Ah, ah! Bebebebu, bu, bu, estou me afogando, meus amigos. Perdôo a todo mundo. Adeus, In manus. Bu. bu. buuu. São Miguel de Aures, São Nicolau, por esta vez e sempre, eu vos faço o voto e a Nosso Senhor, que, se me ajudares (quer dizer se me puserdes em terra fora deste perigo aqui) erguerei para vós uma grande capelinha [...]. - Pelas virtudes, disse Frei Jean, do sangue, da carne, do ventre, da cabeça, se eu ainda te ouvir lamuriar, corno dos diabos, vou te arranjar, como marinheiro velho. Virtude de Deus, e se o jogássemos no fundo do mar? Chefe dos remadores, oi! gentil companheiro, assim meu amigo. Segurai bem. Verdadeiramente, o negócio está sério. Parece que todos os diabos desembestaram hoje ou que Prosérpina está em trabalho de parto. Todos os diabos estão soltos e dançando (RABELAIS, Livro IV, 1991, p. 99). 
Neste diálogo da iminência do trespasse, que representa "como os personagens enfrentaram uma tempestade" (RABELAIS, 1991; cap. XIX, L. IV) as falas, os hinos, os santos, preceitos bíblicos e orações recebem contornos epifrásicos apenas com aparência dessacralizada - mesmo com a presença de Prosérpina no discurso. O crente reclama das rezas e o medroso exagera suas promessas e o valor do amigo-padre na hora do perigo. Note-se o paralelismo entre as falas: este recurso da dupla é comumente utilizado por Rabelais, principalmente na construção de Panurge.

Por outro lado, a dessacralização é aparente, pois durante muito tempo, a Igreja católica foi obrigada a se questionar sobre a presença do cinismo em seus preceitos. Essa corrente filosófica destronante dos absurdos mundanos e, principalmente, por ela ser totalmente contrária à supressão da liberdade imposta pela instituição incomodava e rivalizava com os Evangelhos (similitude no despojamento). Mas é inegável a influência desse pensamento durante a Idade Média e no Renascimento. Além da liberdade da palavra, uma das maiores dificuldades do clero era lidar com os preceitos de despojamento material que coincidiam com o que pregavam e era exatamente o contrário do que fazia a Igreja na sua acumulação de bens e capital. Há sopros desta corrente filosófica nos personagens de Rabelais, principalmente Pantagruel, Panurge e Frei Jean.

Outra problemática era a caracterização de argumentos cínicos como a heresia, visto que muitos pensadores, tais como Santo Agostinho e São Tomás de Aquino dedicaram-se à compreensão dessa corrente e utilizaram-se de imagens e referências na construção de argumentos e de artifícios textuais cínicos (em nome da Ordem). A prova dessa incapacidade de acusar essa corrente e de negá-la completamente transparece no Inferno de Dante, quando Diógenes é colocado no Limbo junto com os filósofos pagãos. Além das referências diretas a ele e a Luciano, espalhadas pelos cinco livros, a Viagem de Alcofribas à boca do Gigante Pantagruel (autor personificado), o ditos satíricos, a barriga como mestre das artes, o mundo dentro de uma garrafa (vol. V) confirmam o riso menipéico espalhado pelas páginas de aventuras, viagens e banquetes, afinal morre-se por rir, morre-se de tanto rir:

\footnotetext{
Morrer por rir, morrer de rir: três elementos congruentes do Quarto Livro de 1552 convidam a repensar a relação entre a morte e o riso. Por um lado, no contexto do carnaval e do jogo por outro lado, pela organização interna da obra e, mais precisamente, na perspectiva aberta pelo prólogo: "queiramos a mediocridade". No centro desta investigação, a articulação de dois conceitos aparentemente inconciliáveis: o exagero carnavalesco e a "mediocridade" evangélica (DELOINCE-LOUETTE, 2001, p. 103-112; tradução nossa).
}

Frei Jean e Panurge fazem a reconciliação estilizada do concílio e carnaval. O primeiro personagem é um ex-monge, um representante direto da junção entre os cinismos pagão e o medieval cristão (que impregnam o discurso rabelaisiano). Sua presença permite o jogo cômico-paradoxal com as formas sérias de comportamento. Temos um membro do clero que se empanturra, bebe, xinga e que conhece a fundo o breviário a ser parodiado com o sangue, a carne, o ventre e a cabeça. Para Bakhtin (2002a, p. 74), em perspectiva hugoana, Frei Jean é o representante da "tendência democrática" e renovadora do clero e o portador de uma importante quantidade de sentenças transpostas da realidade da época. Panurge, por sua vez, representa o bufão sábio que incide no pensamento paradoxal, confrontando, muitas vezes, pelos atos e discursos, a paradoxia evangélica, tão utilizada pela Igreja para moralizar. Suas atitudes despojadas fazem parte de uma práxis cínica medieval carnavalizada. Os diálogos entre estas duas forças-ideológicas não só reinventam discussões medievais, mas as atualizam e conjugam elementos de uma filosofia popular 
corrente no Renascimento. Na passagem acima, enquanto o Padre se impacienta e xinga, o bufão faz promessas para salvar a própria pele. Os gritos de desespero de um, reverberam na impaciência e domínio da fé do outro. O elemento religioso é parodiado pelo Frei, ao passo que a fé de Panurge é exagerada - nomes de Santos, promessas de capelas simplesmente pelo medo de morrer. Para Bakhtin, esta marca do bufão-sábio pode ser aferida no longo debate filosófico travado por ele (no Livro II) e na sua "busca existencial" (no Livro III) para saber se deveria se casar. Uma encarnação luciânica mesclando a sátira grega e romana com a astúcia e a tolice sábia do bufão medieval.

Neste sentido, o imaginário rabelaisiano, estudado por Bakhtin, focaliza a concretude corporal e a heroificação paródica daquilo que os nobres da Antiguidade denegavam e daquilo que a Igreja tentou sublimar da realidade humana (chamando de pecado): a comida, a bebida, o riso, a fala festiva, os excrementos, os gases, a vida sexual. Essa valorização da uma topografia corporal é uma postura subversiva e confronta o mundo da ordem - ou recorda que somos carnais. Os personagens de Rabelais parecem dizer: eu não tenho um corpo; eu sou um corpo.

Fundamentando-se nas práticas populares e parodiando as sérias no contexto social e no universo sepulcral, Rabelais confrontava diretamente o medo da morte (e do pecado). Com isso, desmascarava a pregação de uma vida ascética e embotada, o jejum imperioso e resignado, o silenciamento e o alheamento diante da alegria. Degradando os cerimoniais e as ideologias estratificadas, contrapunha-se à visão vertical-hierárquica (como o fizeram depois Quixote e Sancho com os ideais cavaleirescos e os clowns tagarelas de Shakespeare).

Os festins pantagruélicos constituíam um sistema verbal que incidia no vocabulário da praça (o antigo paço cemiterial) e possibilitavam o reavivamento de um sistema de injúrias e subversões (que sobreviviam oralmente) num campo de produção do conhecimento horizontalizado e que encontra sua mais plena manifestação no romance.

Como nos mostra Bakhtin em Questões de Literatura e estética, com a Morte, a Loucura, a "Idiotice", a "Ebriedade", o literário aproxima-se dos gêneros macabros e divertidos que, mesmo oficializados, nunca perdiam a força carnavalesca. Aproximando o discurso sério-oficial e filosófico da Antiguidade e a presença dos preceitos católicos (para evitar quaisquer problemas com a Inquisição) Rabelais erigiu sua obra com ideologias e representações que se interpenetraram ao longo dos séculos. Mas enformou seu caminho literário inserido em uma tradição oral de ébrios e mentirosos patéticos (BAKHTIN, 2002b, p. 164-210). Desde o primeiro prólogo, culminando com o "mundo dentro de uma garrafa" verifica-se o culto à alegria e a presença do corpo como elemento anatômicofísico que vive e que luta (BAKHTIN, 2002b, p. 211-362). Os preceitos pantagruélicos, por sua vez, estão plenos de um catolicismo carnavalizado - cuja religiosidade nunca é negada. Na ressurreição, na força do conjunto, no grupo peregrinando de um lugar a outro, o mundo se transforma em algo alegre e suportável.

$\mathrm{O}$ exagero, deliberadamente acentuado, confronta o imaginário medieval e o evento passa a ser focalizado por uma ótica moderna de congregar a bebida, a comida, o baixocorporal e a putrefação no mesmo festim, na mesma arena. Bakhtin dá os exemplos primordiais de Boccaccio e Shakespeare (BAKHTIN, 2002b, p. 211-362) que mostram uma morte que prescinde da vida para existir. Como diz Victor Hugo em William Shakespeare:

\footnotetext{
${ }^{5}$ Essa tradição congrega Apuleio, Rabelais (Panurge), Shakespeare (Clowns e Fools), Machado (Quincas Borba e Rubião), Dostoiévski (Príncipe Míchkin n’ O Idiota).
} 


\begin{abstract}
Rabelais viola o monge, pisoteia o bispo, atropela o Papa e gargalha como um chocalho. Os sinos soam como toxinas. Meu Deus! Puta que pariu! Eu vejo Rabelais como uma grande festa, agônica, uma festa onde os erros se transformam em soluços. E vamos gargalhar do mesmo jeito. Afinal, a morte está servida na mesa. A bebida é a última gota de um último suspiro. Que grande farra agônica. O intestino é o Rei. Toda a festa do velho mundo está morta. E Rabelais cria a maior dinastia do estômago - Grandgousier, Pantagruel e Gargântua (HUGO, 1864, p. 74; tradução nossa).
\end{abstract}

A morte está posta para ser confrontada, discursada e adquirir um sentido (metafísico ou social). Ela teria um vínculo estreito com a memória folclórica e com o tempo fecundo e produtivo. Da comunhão coletiva e laboriosa da terra, do espelho de um mundo que "evolui" e que se transforma, os personagens rabelaisianos se agigantam, mas são leves; praticam uma guerra desmesurada, mas cultuam o amor; servem a uma ordem, mas os impulsos vitais prevalecem e superam hierarquias.

A negação do sério antigo e medieval, o diálogo paródico com os gêneros épicos e bíblicos, com séculos de imposições e inquisições, sobreviveu e foi captada pela pena fálica e a tinta do gozo do honrado e fecundo de AlcofribasNasier (extrator da quintaessência). Nos livros repletos de pantagruelismo os jogos livres e alegres estão dotados de um sentido profundo do homem e da vida, erigindo uma imagem renovada de um "Homero Bufão". Este bobo autor compreende o mundo às avessas e desfigura a realidade a partir de uma pluralidade "vertiginosa" de vozes: "as tempestuosas gargalhadas que tais passagens ocasionam estremecem todos os conceitos da ordem costumeira daquele tempo" (AUERBACH, 2001, p. 238).

A consciência crítica da dimensão patética, a virulência do grotesco e do encontro do universal no romance, capaz de consignar os saberes humanos na forma concreta de um Livro fluente, aberto e totalizante pode ser revisto na análise do inferno saturnal considerado aqui, o "Diálogo dos mortos" do romance rabelaisiano.

\title{
3 A morte pantagruélica
}

Para a análise tanatográfica entre personagens que falam com mortos e que "voltam" para contar, nos concentraremos especificamente no livro II, "Pantagruel, Rei dos Dipsodos".

A opção pauta-se pelos elementos biográficos latentes e pela "descida ao Inferno". Parodiando o discurso grego, temos a Antiguidade heroica na descrição da genealogia de gigantes (RABELAIS, 1991, vol. 1, p. 275-276). Recordemos que Pantagruel, ao nascer, teve a mãe morta. O pai, não sabendo se chorava pela morte da mulher, ou se ria pelo nascimento do filho, fazia as duas coisas ao mesmo tempo, e concluía, entre ladainhas e mementos: "Senhor Deus, é preciso que eu ainda me contriste? [...] conviria chorar menos e beber mais" (Idem, p. 283).

O nome do filho tem uma essência cínica, paradoxal e evoca o riso ambivalente: "Panta, em grego, quer dizer tudo, e Gruel, na "língua hagarena", quer dizer alterado. Querendo significar que, na hora do seu nascimento, o mundo estava todo alterado, e vendo em espírito de profecia que um dia seria o dominador dos alterados" (Idem, p. 280; grifos nossos), desde o nome, olhares desfigurantes se anunciam: gigantes, bêbados, bobos,

\footnotetext{
${ }^{6}$ Em seu prefácio de Cromwell, Victor Hugo, fazendo uma apologia do paradoxo, afirma que a religião caminha com as superstições e que o sublime se envolve com o grotesco. Ele designa três "Homeros Bufões" modernos: Ariosto na Itália; Cervantes, na Espanha; Rabelais na França (apud BAKHTIN, 2002a); Essa ideia será desenvolvida em William Shakespeare. Vide HUGO, 1864).
} 
padres injuriados... Em seguida, infância e juventude são narradas detalhadamente: os brinquedos, os jogos, as experiências do baixo-corporal compõem o universo dos anos de "formação" do pequeno gigante. Comida em exagero, viagens a bibliotecas (enumeração parodiada nas dezenas de livros da época), ensinamentos do pai e o encontro com Panurge, de quem seria amigo por toda a vida. Depois de eventos vividos pela dupla e que cheiram à moinhos de vento (julgamentos paródicos, confusões, banquetes, mulheres) os dados biográficos de Panurge o redefinem: trapaceiro, batoteiro, beberrão, vagabundo, malandro, charlatão, namorador, mendigo, prestidigitador etc.

Mas a notícia de que os Dipsodos haviam invadido o país dos Amaurotas leva os personagens a uma viagem de volta à Utopia para combater um exército de 660 gigantes comandados pelo Rei Anarche. É o exército dos alterados realmente em ação. Panurge, Epistemon, Eustenes e Carpalim são os combatentes alterados e fiéis a Pantagruel. Partindo de Rouen, passando por lugares geograficamente localizáveis (Madeira, Cabo da Boa Esperança etc.) esta aventura sério-cômica os levou a fazer escalas nos reinos de Meden, Uti, Uden, Gelasin, pelas ilhas das fadas e junto ao reino de Achoria ${ }^{7}$ chegaram ao porto de Utopia "distante três léguas e pouco da cidade de Amaurotas" (RABELAIS, 1991, v. 1, p. 378).

Nessa guerra, encontramos a paródia da Ilíada, da Odisseia (descida de Odisseu), Os Evangelhos e um diálogo com A Comédia de Dante.

Antes do conflito, os combatentes pantagruélicos narram suas genealogias e as "nobres características" que o destino lhes dera. Panurge, da linhagem de Zopiro ${ }^{8}$, pretende invadir o acampamento dos inimigos durante a noite, banquetear-se e fartar-se às custas deles e "transar com suas putas" sem ser reconhecido; Epistemon, da linhagem de Sinon" conhece todos os estratagemas, artimanhas e embustes da disciplina militar; Eustenes, da linhagem de Hércules ${ }^{10}$ promete que entrará em todas as trincheiras e que quebrará braços e pernas; e Carpalin, da linhagem da amazona Camila ${ }^{11}$ adverte que saltará com leveza, pois é capaz de caminhar sobre as espigas do trigo sem que elas se dobrem. Nessa passagem, a paródia das genealogias da Ilíada se estende à História de Heródoto: os generais atenienses e os principais guerreiros tinham suas genealogias louvadas para grandeza do nome e para reforçar as qualidades no combate. Cada herói tinha o nome ligado ao seu caráter e isso o predispunha a determinadas ações e formas de lutar. O Destino épico parodiado no romance ganha contornos risíveis pelo fato de cada personagem inventar sua genealogia e não exatamente ser um herdeiro de heróis. Os caracteres de cada figura são individuais e, se cada um deles, realmente é capaz de realizar tais façanhas, isto advém de mérito individual e não mais por pertencerem à uma linhagem nobre.

Pensando que a Ilíada é um poema de guerra, vejamos como, no livro de Rabelais, a batalha se delineia. A princípio, ela tem duas fases. Na primeira, os "valentes soldados" insistem que Gargântua não vá a campo e traçam um plano mirabolante para o combate. A paródia está na inversão. Eles preferem utilizar a astúcia e não o confronto direto para derrotarem o inimigo. Panurge, aos moldes de Odisseu, elabora estratagemas, divide ações

\footnotetext{
${ }^{7}$ Meden, Uti, Uden, Gelasis e Achoria significam em grego, respectivamente, nulo, nada, coisa alguma, trocista e sem medida (RABELAIS, 1991, v. 1, p. 378). Recorde-se o Ninguém, o Nulisseu no episódio de Odisseu contra o Ciclope - Canto IX, que antecede a Catábasis.

${ }^{8}$ Zopiro foi um pitagórico, mecânico ficou famoso por inventar e aperfeiçoar máquinas de guerra. Pelo contexto da guerra a "descendência", nesse caso, antecipa o que o personagem fará.

${ }^{9} \mathrm{Na}$ Ilíada (canto XXIV) ele aparece conversando com Príamo e negando os gregos. Com ódio de Odisseu e Diomedes, ele se torna um traidor. Simbolicamente Epístemon cultiva estratagemas militares e ações sorrateiras.

${ }^{10}$ Símbolo de força e agilidade. Está na genealogia dos gigantes.

${ }^{11}$ Simboliza a leveza feminina, aliada à uma força ágil e versátil.
} 
(artifício de guerra, agilidade, força, destreza). Com isso, derrotam "sutilmente seiscentos e sessenta cavalheiros" (RABELAIS, 1991; cap. XXV). Com fingimentos e performances teatrais eles enrolam os pés dos cavalos e derrubam a todos. Antes que pudessem reagir, Panurge atiça fogo "fazendo com que todos fossem queimados como almas danadas" (RABELAIS, 1995, p. 382). Depois da batalha, um banquete regado a abundante comida, bebida, peidos ambivalentes por parte de Pantagruel (que geraram os Pigmeus) e esculturas grotescas em honra da vitória simbolizam "o espírito criativo sobre a força grosseira e primitiva, tratados de forma carnavalesca" (BAKHTIN, 2002a, p. 183).

Logo em seguida, uma nova batalha se anuncia. Se, no primeiro momento, a inversão paródica se deu pelo artifício, nesse segundo, a inversão é mais radical. Os soldados de Utopia se colocam a beber e a comer com os gigantes inimigos enquanto Pantagruel alcança "bem estranhamente" a vitória contra os Dipsodos e os gigantes. Com estratégias que superariam "os ruídos da batalha dos troianos" (RABELAIS, 1991, vol. 1, p. 393), afinal os deuses estão distantes, o sal na garganta dos soldados bêbados que dormiam e a urina que gerou "um dilúvio particular" fez tão grande destruição que "alguns diziam que era o fim do mundo e o juízo final (RABELAIS,1991, v. 1p. 394). Em meio às imagens épicas e bíblicas o próprio autor projetado, que assina como Alcofribas Nasier ${ }^{12}$, parodia os Aedos e Rapsodos com uma fala efusiva:

Ó quem poderá contar agora como se portou Pantagruel contra os trezentos gigantes? Ó minha musa! Minha Calíope, minha Tália, inspira-me agora! Restaura o meu espírito, pois eis o a-bê-cê da lógica, eis a armadilha, a dificuldade de não se poder expressar a terrível batalha que se travou. Ah! A minha vontade de ter agora um garrafão do melhor vinho que jamais beberão os que lerem esta história tão verídica! (RABELAIS, 1991, v. 1, p. 394).

Autoconsciência e carnavalização caminham juntas nessa paródia épico-cínica dos cantos Homéricos. $\mathrm{O}$ exagero alarga as fronteiras e atualiza velhas discussões e visões de mundo. Depois de questionar Heródoto (cap. XXVI, p. 386) que narrou a famosa batalha vencida por Temístocles (que tinha poucos homens) contra Xerxes (que dispunha de trezentos mil soldados) o divertido narrador assume que sua verdadeira musa é o vinho. Diante da dificuldade de expressar a terrível batalha, seu a-bê-cê é o culto à ebriedade. Este culto delineado desde as primeiras linhas do prólogo do livro I (Gargântua) compõe o caráter beberrão e festivo desse narrador narigudo que destrona o mito grego e o mito cristão:

[...] na composição deste livro senhoril, não perdi, e jamais empreguei um outro tempo, do que aquele gasto para tomar minha refeição corporal, a saber, bebendo e comendo. São estas as horas mais adequadas para escrever sobre essas altas matérias e ciências profundas, como bem fez saber Homero, paradigma de todos os filólogos (RABELAIS, 1991, p. 35 - Prólogo do livro I).

Equiparar o ato de escrever aos atos de comer e beber é a celebração máxima do pantagruelismo. Diante do mundo, o medo metafísico da morte começa a desaparecer. Seu "realismo criatural" (AUERBACH, 2001, p. 241), ligado à "cultura popular carnavalesca" (BAKHTIN, 2002a) permitiu o conjunto de imagens ambivalentes e uma tradição moderna que começa em Rabelais e continua em Cervantes, Sterne, Dostoiévski e Machado. Neste caso, o paradigma "filológico" da modernidade é este imenso romance. A tanatografia, neste caso, tenta ampliar este corpus para mapear as ocorrências da "versões populares

\footnotetext{
${ }^{12}$ Anagrama de François Rabelais de cunho corpóreo-topográfico. Nasier remete-se ao nariz que, segundo a tradição popular, seria fálico e sugeriria uma proporção peniana.
} 
transmitidas oralmente" (JACQUIN, 2008, p. 30-42) e para fazer uma reflexão, sempre a partir do literário sobre "porque os mortos retornam" (BAYARD, 2008, p.17-29).

No gigantesco combate, enquanto os chefes gigantes se batem em duelo, entre pantomimas e contação de fábulas por Panurge, os soldados comem, bebem e assistem à batalha em um verdadeiro festim de guerra. Com a "ajuda de Deus" Pantagruel vence o confronto com Lobisomem (melhor soldado do Rei Anarche). Vendo seu chefe derrotado, os gigantes se levantam e se lançam contra ele, que derruba a todos. Enquanto isso, Panurge, Carpalim e Eustenes degolavam os que caíam e Pantagruel ceifava cabeças: "Foi quando Pantagruel derrubou um que se chamava Riflandouille, que estava armado de um alto aparelho, formado por pedras de Grisão, uma lasca das quais cortou inteiramente a cabeça de Epistemon" (RABELAIS, 1991, v. 1, p. 401).

Este acidente é o motivo rabelaisiano para a descida ao Inferno. Não há uma missão, não há um bode expiatório. Ao contrário, a descida e a ressurreição são vividas por um simples soldado pantagruélico. Mas, ao invés de enterrar o defunto amigo, a proposta é a ressurreição que, no plano do leitor, é paródia direta da ressurreição dos Evangelhos. Nem enterrado, nem abandonado, mas impedido de viver a própria morte. Neste mundo de fronteiras o respeito aos mortos (JACQUIN, 2008, p. 35), antigo e cristão, é divertidamente desafiado.

Entre lamentos exagerados e impropérios típicos de práticas fúnebres medievais e renascentistas, Panurge promete trazer o amigo de volta com um unguento ressuscitador: "Depois de ligar veia por veia, espôndilo por espôndilo e dar pontos Epistemon voltou a respirar, depois abriu os olhos, depois bocejou, depois espirrou, depois deu um peido com todo o gosto - garantia inquestionável de sua cura" (RABELAIS, 1991, v. 1, p. 403). O ressuscitado, ao acionar todos os orifícios que o ligam ao mundo, toma vinho, come um assado e lamenta ter sido trazido de volta tão rápido, pois dizia que conversou familiarmente com Lúcifer e que todos os diabos eram bons sujeitos naquele inferno alegre. Somente depois do peido, da bebida e da comida ele realmente acredita que ressuscitou. Durante o banquete um inferno alegre, ao contrário do frio e amedrontador inferno de Dante, é descrito e celebrado.

Epistemon, não por acaso este nome para o ressuscitado, afirma que havia se divertido muito no "inferno e nos Campos Elíseos" (RABELAIS, 1991, v. 1, p. 404) e celebra a vida e a alegria de viver. Depois de lutar, morrer, descer à mansão dos mortos, ressuscitar, usar os orifícios, ele conta o que viu. Exatamente como o fez Odisseu (sem ter morrido) ou como Cristo que morre e volta corporificado e banqueteia-se com os seus para provar sua sacralidade.

Elegendo e enumerando nobres de tradições elevadas antigas e medievais, a paródia menipeica realiza-se por uma longa enumeração. Os detalhes espaciais não são explorados e apresentam-se desnecessários. Mais uma vez as eras anteriores são confrontadas no mesmo campo topográfico. A longa nominação começa com Alexandre e deslinda o princípio de inversão saturnal do "inferno rabelaisiano": todos os nobres são "condenados" a trabalhos "inferiores" ou são criticados com epítetos destronantes. Eis alguns exemplos que fundem herois antigos e medievais: "Alexandre, o Grande, remendava calções velhos; Xerxes vendia mostarda; Aquiles malcriadão e enfeixador de feno, Agamenon lambedor de panelas, Ulisses ceifero; Nestor vagabundo, Príamo vende panos velhos, Dario limpador de latrinas; Lancelote é esfolador de cavalos mortos" (RABELAIS, 1991, v.1, p. 404) e todos:

[...] os cavaleiros da mesa redonda são pobres remadores que fazem a travessia dos rios Cócito, Flegeton, Estige, Aqueronte e Leto, quando os senhores diabos querem passar na água [...]. Mas para cada passagem só ganham um piparote no nariz e à noite um pedaço de pão duro (RABELAIS, 1991, v., p. 404). 
Os nobres, os guerreiros épicos e entidades romanas aparecem fazendo trabalhos espúrios e humilhados pela condição inferiorizada. O óbolo sagrado é substituído pelo piparote e pelo pão duro. No universo rabelaisiano a casta de cavaleiros arturianos são "barqueiros" condenados a levarem os diabos a passeio.

A confrontação com o épico (hadesiano) e com o religioso (dantesco) reforça a eficácia paródica desse diálogo do morto que volta para contar e que condensa a cultura antiga e a medieval. Os nobres e figuras eclesiásticas também estão lá: “[...] Júlio César e Pompeu são janotas; Don Pedro de Castela poetastro, Papa Júlio vendedor de pastéis; Nicolau papa terceiro é fabricante de papel; o Papa Alexandre é apanhador de ratos e o Papa Xisto tratador de varíolas" (RABELAIS, 1991, v. 1, p. 406) porque aquele que "teve varíola neste mundo, tem no outro". E na enumeração abrangente do imaginário europeu entram também os cavaleiros dos romances de cavalaria: "Galieno Restaurador, caçador de toupeiras, Matabruna limpadora de lixívia". E as personagens femininas lembradas pela história também recebem seu quinhão: "Cleópatra é vendedora de cebolas, Helena criadagrave, Dido vendedora de vinho; Lucrécia é estalajadeira (RABELAIS, 1991, p. 406-407).

Enfim, todos condenados ao trabalho, ao passo que os exagerados em vida, merecem a festa ad eternum. Obrigados às penas da servidão, enquanto aqueles que foram miseráveis são servidos e tem uma vida "justa". Condenando os vícios dos ricos e poderosos, o inferno cínico-paradoxal inverte os papéis. Moralista como os julgamentos menipéico e cristão, essa inversão carnavalesca mostra os filósofos e o indigentes vestidos dignamente, banqueteando-se e divertindo-se com damas e com muito dinheiro (escudos de sol). Epistemon fora convidado a beber vinho "teologicamente" em meio ao comércio de charlatões, vendedores de indulgências, mendigos (Ciro, por exemplo) como se o inferno fosse uma verdadeira feira medieval.

Bakhtin (2002a), concentrando-se nas imagens da ressurreição e do banquete desta passagem, mostra a forte presença das saturnais e como a inversão carnavalesca coroa os pobres e destrona os ricos. As enumerações enfeixam condições imprevistas, injúrias e a ênfase no baixo-corporal. Para ele, os infernos têm um caráter popular e uma alegria da "festa dos escravos". Desse ponto de vista acentua as diferenças entre Luciano e Rabelais considerando a descida do primeiro mais formal e menos festiva, concentrada no estilo socrático que se constrói para chegar a determinada conclusão. A condição dos poderosos é diferente também. Mesmo que ambos tenham o caráter moralizante, em Luciano os personae apenas lamentam a condição cadavérica e o que perderam da condição vivaz, ao passo que em Rabelais eles são obrigados a trabalhar e a servir.

As saturnais, de certo modo, estão presentes nos "diálogos infernais", compondo uma longa história de "artifícios sério-cômicos desconexos [emprestando] uma nova tópica a velhos escárnios"” (KINNEY, 2007, p. 337). Pelo viés da morte alegre e cínica atinge parte da população infernal e, principalmente, a percepção de quem observa (Epistemon, os ouvintes-personagens e o leitor). Se os condenados à miséria e à mendicância são "castigados" e não há festa para eles, isto faz parte do pacote moralista cínico-cristão que enforma esta saturnal romanceada.

Se na Odisséia o riso catabático inexiste, abarrotado pelo horror e clima sombrio, e se "o riso de Luciano é abstrato, exclusivamente irônico, privado de toda alegria verdadeira" (BAKHTIN 2002a, p. 340), em Rabelais a gargalhada sepulcral reverbera. Para o russo, na épica, as figuras são colocadas a serviço da nobreza e da hierarquia, na sátira menipeia, as inversões são meros castigos, dotados de uma moral cínica e até com certo grau de estoicismo. Em Rabelais, essas imagens são retomadas como julgamento e punições, todas elas descritas com alegria e celebradas no banquete ao redor daquele que voltou para contar. A imagem do Hadesodisséico e diogênico foi explorada pela Igreja, por 
isso o jocoso emoldura a cena e permite ao escritor francês dialogar com os milagres medievais e as ressurreições bíblicas ${ }^{13}$.

Bakhtin não menciona o castigo, pois sua leitura é tomada pelo espírito saturnino, fazendo com que ele não se refira ao fato da morte e concentre-se tão somente em Epistemon redivivo. O importante da sua leitura é a percepção da inversão carnavalesca presente nos cinco livros. O gigante, o bobo astucioso, os cristãos cínicos (frei Jean) e personagens (amigos dos gigantes) provocam desfigurações paródicas. Dessa postura paradoxal irrompem as contradições humanas e as fragilidades diante da natureza, do destino e dos "defeitos-pecados". A prova cabal dessa inversão cínica é que depois do relato do amigo ressuscitado, o rei derrotado dos Dipsodos é obrigado a trabalhar preparando-se para o labor infernal. Os heróis rabelaisianos, por sua vez, como os cínicos antigos, preparam-se para um Banquete eterno e a zombaria no além.

A imagem das pessoas finadas agrega a alegria contagiosa e o imaginário dos Campos Elísios. Nesse sentido, os lugares, o Hades grego homérico e aristofânico, o romano de Virgílio e Luciano e o Inferno Cristão e Dantesco nutrem o Inferno Saturnal de Rabelais e ainda conjugam pontos em comum. Nas representações, a condição ínfima de vagar como sombra, esqueletos (com nomes!) lamentando e pessoas em uma condição diferente da anterior se ligam pelo riso e punições. A divergência, nesse sentido, são os espaços representados, as tensões características de cada gênero - na épica, a voz do aedo substituída pela do personagem Odisseu; na sátira, os diálogos dramático-socráticos; no romance, a roda de ouvintes atentos às descrições autônomas de um personagem específico.

$\mathrm{Na}$ Odisséia, um vivo desce ao mundo dos mortos, divide informações, sentimentos, lamentos e volta para contar essa história. Não há testemunhas e é preciso compactuar com o personagem. Considerando o que o poema épico tem de realidade (religiosa) para os antigos, e de fantasia (para o mundo cristianizado), o leitor tem informações pelo olhar de Odisseu - um aedo estilizado. $\mathrm{O}$ mais interessante é o fato de seu relato ser "ipsislitteris" o relato de Homero. Na Ilha dos Feácios, o Astucioso definiu discursivamente parte de suas próprias memórias épicas - sem precisas da Musa para tal fato/ato.

Nos diálogos de Luciano de Samósata a representação é dramática. Há notícias da descida de Odisseu, mas no instante das ações, todos os personagens são moribundos ou deuses. A sátira atende a uma moral específica e à conclusão maior delas: a lembrança de que não há volta. Um pessimismo cético irrompe e uma total desilusão perante o trespasse reside na postura desprendida e despojada do cínico. O mais importante, no que diz respeito ao contexto dialógico do mundo é o olhar que repensa e confronta o passado e a discussão do cotidiano (realismo sério-cômico). A desfiguração da moeda acontece no olhar subversivo da morte, na gargalhada sepulcral e na impassibilidade cínica diante da dor de morrer.

Se tomarmos a obra de Dante, como summamáxima de representação dos espaços cristãos medievais, ocorre uma hierarquização de cada localidade. O juízo final define o encaminhamento da alma e o Destino depois do trespasse. A problematização do presente começa a individualizar-se e Dante-personagem passeia pelas galerias infernais, purgatoriais e paradisíacas - guiado por Virgílio nos Inferno e Purgatório e por Beatrice no Paraíso. Sua voz certamente ressoa parodiada na hierarquia rabelaisiana e na distribuição das funções das pessoas. O Inferno descrito por Epistemon, mais especificamente, é tomado de imagens cujo espírito predominante é a inversão. O castigo, se ele realmente

\footnotetext{
${ }^{13}$ Para Bakhtin (2002a), o episódio parodia a ressurreição de Lázaro (emoldurada pelo banquete evangélico).
} 
existe, é o trabalho. Quanto ao estilo, Dante utilizava mudanças rápidas de cena para manter o medo cósmico no leitor e permitir a tessitura de diálogos entre o personagem vivos e os mortos. Se os hereges e ímpios começam a individualizar-se e o narrador mantém seu tom prosaico e forte perante o mundo (presente) organizado nos espaços sagrados, em Gargântua e Pantagruel, obra de fôlego avantajado, a morte aparece sempre ambivalente. Os personagens, por sua vez, têm mais autonomia na representação catabática do inferno. Isto confere-lhe um colorido especial e a não centralidade no que diz respeito ao juízo final, mas à vida cotidiana, também retira o grande mito cristão do centro embora não haja pretenso ateísmo (como equivocadamente sugere Lucien Febvre).

Nos combates, nas pestes, nas tragédias, nos eventos coletivos há sempre regeneração. Essa alegria é traduzida pela visão carnavalizada e pela imagem da ressurreição. Nesse sentido, o inferno também é um lugar próspero, movimentado, como o ambiente das feiras. Os seres comem, dançam, bebem, amam, trabalham, mendigam, regozijam-se. Mudam-se papéis, mas as necessidades continuam as mesmas: maiores viram menores, miseráveis e filósofos são beneficiados pela nova condição. A morte não iguala, ela inverte. Ela não enterra, mas integra-se à vida. Neste diálogo o "modelo cínico de um eu naturalmente livre e autônomo" (GOULET-CAZÉ 2007; BRANHAM, 2007, p. 29) amplia-se em um grande grupo e no conjunto de vozes em constante diálogo e protoconsciente do inacabamento.

As imagens risíveis contadas por Epistemon ressuscitado para os amigos que comem e bebem atentos são menções dialógicas à tradição de mortos que falam, agem, lamentam e purgam nas variantes do Hades. Panurge interrompe e sente vontade de contar. Garante ter visitado também "os buracos do mundo" - sentido dúbio: baixo-corporal e locusdesfigurante. Nesse caso, a representação da descida amplia-se: Epistemon morre e desce ao inferno. Por ter sido libertino e livre tomou o lugar entre os privilegiados e o tempo (distendido) que esteve por lá o permitiu ver os grandes - sempre humilhados e servis. Panurge, como Odisseu, também é inventivo e sugere suas viagens cínicas pelos buracos (ambivalentes) do mundo. Ao ressuscitar o amigo duplica suas visões, seu discurso sobre o trespasse.

\section{Conclusão}

Nesses locais "desconhecidos" a alegria é maior ou menor, as diferenças acentuamse, são invertidas ou se equiparam. Em todos os lugares de descida apontados aqui, da Antiguidade até Rabelais, as diferenças sociais são ressaltadas. Em maior ou menor grau há lamentos daqueles que gostariam de estar vivos e a alegria daqueles (cínicos, filósofos, pobres) que desfrutam de benefícios na Necrópole.

François Rabelais, ao transformar esse tema tão contundente e conflitante na era moderna, renova a representação dos discursos dos mortos. Dentro de uma longa tradição cultural-literária, ele a renova por colocá-la em consonância com o individualismo e conjugar cinicamente o fato de que o homem sabe que morre e sabe que tem fome. Neste sentido, é o discurso do homem o ponto central da temática e não exatamente o elemento topográfico (como em Homero e Dante).

Cabe ao pesquisador deste novo milênio relativizar as menções radicais de Bakhtin ao "abastardamento e degenerações" no campo literário e procurar tanatografias em Cervantes, Shakespeare, Dostoiévski, Machado e mapeá-las em realizações do Século XX e XXI (Pirandello, E. Verissimo, G. Wittkop, Borba Filho, Suassuna, Saramago, dentre outros). 
O vaticínio de Pantagruel certamente traz uma reflexão espiritual e menipeica das dores existenciais e convidam aos ecos da tradição:

[...] pois a fome está no corpo; para a remediar dilata-se o estômago, turba-se a vista, as veias sugam a própria substância dos membros carniformes e retiram em baixo esse espírito vagabundo, negligenciam o tratamento de sua cria a hóspede natural, que é o corpo. [...] a esse propósito lícito é alegar a autoridade de Homero, pai de toda a filosofia, que diz que os gregos, então, logo puseram fim às suas lágrimas de luto por Pátroclo, o grande amigo de Aquiles, quando a fome se declarou e seus ventres protestaram, mais lágrimas não os fornecendo. Pois, no corpo esgotado por longo jejum, mais não havia para chorar e lacrimejar (RABELAIS, 1991, v. 1, p. 483).

O cinismo mais radical contrabalança essas imagens e aproxima os pontos de vista saturnal dos mortos Antigos e Medievais e os Mortos Modernos. Sejam eles tomados como verdade ou mito, versão narrativa da realidade, a compreensão tanatográfica do mundo prosificado conjuga o Cinismo, os gêneros literários e suas transformações ao longo dos séculos. Injuriante e desprendido, autor e tagarela, Alcofribas Nasier acredita na ambivalência e equivalência da condição humana e emenda mais um capítulo nessa história: o discurso individualizando-se na confrontação paródica da ordem. Da soma de mentalidades, com o universo saturnal nasce um dos grandes romances da modernidade: filosófico, contingente, galhofeiro, eterno...

\section{REFERÊNCIAS}

ARIÈS, P. História da morte no Ocidente. Tradução Priscila Viana de Siqueira. Rio de Janeiro: Ediouro, 2003.

ARIÈS, P. O Homem perante a morte. 2. ed. Tradução Ana Rabaça,Mira-Sintra; Mem Martins: PublicaçõesEuropa-América, 2000. 2 v.

AUERBACH, E. A Cicatriz de Ulisses. In: Mimesis: a representação da realidade na literatura ocidental. 4. ed. São Paulo: Perspectiva, 2001.

BAYARD, Florence. Porquoi les morts reviennent-ils? In: BOULOUMIÉ, Arlete. Les vivants et les morts - littérature de l'entre-deux mondes. Paris: Imago, 2008. p. 17-29.

BAKHTIN, Mikhail. A cultura popular na Idade Média e no Renascimento: o contexto de François Rabelais. São Paulo: Annablume; Hucitec, 2002a.

BAKHTIN, Mikhail. Questões de literatura e de estética: a teoria do romance. São Paulo: Annablume; Hucitec, 2002b.

DELOINCE-LOUETTE. Mourir de rire, mourir pour rir e dans Le Quart Livre. Recherches\&Travaux, v. 67/2005, [Enligne], mis enlignele 30 septembre 2008. Disponível em: <http://recherchestravaux.revues.org/index267.html>. Consulté: le 27 août 2012. p. 103-112.

FEBVRE, Lucien. O problema da incredulidade no Século XVI: a religião de Rabelais. Tradução Maria L. Machado. São Paulo: Companhia das Letras, 2009.

GOULET-CAZÉ, Marie-Odile; BRANHAM, R. Bracht (Org.). Introdução. Os cínicos - O movimento cínico na Antiguidade e o seu legado. São Paulo: Edições Loyola, 2007. 
HUGO, Victor. William Shakespeare. Paris: Nelson Éditeurs, 1864. Disponível em: <http://www.archive.org/stream/williamshakespea00hugo\#page/n1/mode/2up>. Acesso em: 27 ago. 2012.

JACQUIN, Gerard. Le motif du mort reconnaissant dans Richard le Beau, roman du XIIIe Siècle. In: BOULOUMIÉ, Arlete. Les vivants et les morts: littérature de l'entre-deux mondes. Paris: Imago, 2008. p. 30-42.

KINNEY, Daniel. Herdeiros do cão: identidade cínica na cultura medieval e renascentista. In: GOULET-CAZÉ, Marie-Odile; BRANHAM, R. Bracht (Org.). Introdução: Os cínicos - O movimento cínico na Antiguidade e o seu legado. São Paulo: Edições Loyola, 2007.

RABELAIS, F. Gargântua e Pantagruel. Tradução David Jardim Júnior. Belo Horizonte; Rio de Janeiro: Villa Rica, 1991. 2. v.

SANTO AGOSTINHO. A cidade de Deus. 3. ed.. Lisboa: Fundação Calouste Gulbenkian, 2008. v. 2

SILVA JÚNIOR, Augusto Rodrigues. Cultura popular, topografia corporal e inacabamento: a crítica rabelaisiana de Victor Hugo. Brasília: Universidade de Brasília; 210 Hugo Anos, 2012. (mimeo).

SILVA JÚNIOR, Augusto Rodrigues. Morte e decomposição biográfica em Memórias Póstumas de Brás Cubas. 216 f. Tese (Doutorado) - Instituto de Letras, Universidade Federal Fluminense, Niterói, 2008. Disponível em: <http://www.bdtd.ndc.uff.br/ tde_busca/arquivo.php?codArquivo=2500> Acesso em: 15 mar. 2010.

SOUSA, Eudoro. Catábases: estudos sobre viagens aos infernos na Antiguidade. São Paulo: Annablume Clássica, 2013.

Recebido em: 08 de janeiro de 2012.

Aprovado em: 31 de setembro de 2012. 